\title{
Cancer incidence in urban bus drivers and tramway employees: a retrospective cohort study
}

\author{
Helle Soll-Johanning, Elsa Bach, Jørgen H Olsen, Finn Tüchsen
}

\begin{abstract}
Objective-To investigate the risk of cancer associated with exposure to air pollution among bus drivers and tramway employees.

Methods-A retrospective cohort study of 18174 bus drivers or tramway employees in Copenhagen in the period 1900-94. Data on employment were obtained from company files. Information on cancer was obtained from the Danish Cancer Registry.

Results-Findings showed that bus drivers or tramway employees had an increased risk of all malignant neoplasms (standardised incidence ratio (SIR) 1.24, 95\% confidence interval (95\% CI) 1.19 to 1.30). The relative risk was significantly increased for both men and women (SIR $1.24,95 \%$ CI 1.19 to 1.30 and $1.28,1.06$ to 1.53, respectively). People employed for $<3$ months had no increased risk of cancer $(1.04,0.81$ to 1.31$)$. For men who were employed for $>3$ months the risk of lung cancer $(1.6,1.5$ to 1.8$)$, laryngeal cancer $(1.4,1.0$ to 1.9$)$, kidney cancer $(1.6,1.3$ to $2.0)$, bladder cancer $(1.4,1.2$ to 1.6$)$, skin cancer $(1.1,1.0$ to 1.2$)$, pharyngal cancer $(1.9,1.2$ to 2.8$)$, rectal cancer $(1.2,1.0$ to 1.5) and liver cancer $(1.6,1.2$ to 2.2$)$ was significantly increased. For women employed for $>3$ months the risk of lung cancer was significantly increased $(2.6,1.5$ to 4.3).
\end{abstract}

Conclusion-This cohort study shows that bus drivers and tramway employees are at an increased risk of developing several types of cancer. This might be due to the exposure to air pollution during working hours or to other risk factors, primarily smoking.

(Occup Environ Med 1998;55:594-598)

Keywords: lung cancer; air pollution; epidemiology

Substantial epidemiological evidence has associated air pollution with mortality and morbidity due to respiratory diseases ${ }^{12}$ and cancer. ${ }^{3}$ Air pollution consists of a complex mixture of thousands of chemical compounds. The adverse health effects of most of these compounds are still to be studied. Many of the compounds are formed by incomplete combustion of fossil fuels, and they are present in the exhaust gases from petrol and diesel powered vehicles. A working group under the International Agency for Research on $\mathrm{Cancer}^{4}$ has reviewed the evidence for carcinogenicity of engine exhaust fumes based on epidemio- logical studies, experimental studies in animals, and other relevant biological data. It found inadequate evidence for the carcinogenicity of petrol engine exhaust in humans and limited evidence for the carcinogenicity of diesel engine exhaust in humans.

An urban-rural gradient in incidence of cancer in Denmark is evident, ${ }^{5}$ although the levels of air pollution are considered to be relatively low in Copenhagen compared with large cities around the world. Due to the fact that our present knowledge of levels of exposure to environmental agents in the general population is limited, it is difficult to estimate the contribution of such agents, if any, to the overall risk of cancer and other diseases.

In this study we focused on the risk of cancer in a cohort of people who were regularly exposed to air pollution, especially vehicle exhaust fumes, through their job-namely, all people ever employed as a bus driver or tramway employee in Copenhagen or in the suburban area of the city.

\section{Material and methods}

Denmark has a longstanding tradition for well maintained employment files with information on an individual level. Personal and occupational data on employees in public companies are usually reliable as such information often underlies a future pension payment. In 1974, $80 \%$ of all bus companies in Copenhagen and the suburban area were merged into one company: The Copenhagen Traffic Company, District 1 (CTC), and all employment records were gathered in one archive. From this archive we investigated all people ever employed by CTC in the period from 1 January 1900 to 1 May 1994. Even the data covering the earlier years are reliable and well maintained. In 1965 there were, according to CTC statistical reports, 1500 tramway employees and 900 bus drivers. After 1972 there were no tramways in Copenhagen. We cannot distinguish between bus drivers and tramway employees. However, tramway employees were exposed to the same air pollution from traffic as the bus drivers. Information on name, date of birth, or personal identification number, place of birth, and start and end of work periods were computerised. Of the 19489 people initially registered, 832 $(4.3 \%)$ were excluded due to missing data, obviously incorrect data-for example, date of birth after first day of employment - or duplicate registrations. The excluded data were distributed equally all over the whole period. The remaining 18657 bus drivers and tramway employees were linked with the Central Population Register (CPR) for verification of 
Table 1 Descriptive characteristics of 18174 bus drivers and tramway employees in Copenhagen

\begin{tabular}{lrr}
\hline Characteristic & \multicolumn{2}{c}{$\%$} \\
\hline Sex: & 16203 & 89 \\
Male & 1967 & 11 \\
Female & & \\
First employment (y): & 526 & 3 \\
1900-19 & 233 & 1 \\
$1920-29$ & 1092 & 6 \\
$1930-39$ & 3123 & 17 \\
$1940-49$ & 1187 & 7 \\
$1950-59$ & 712 & 4 \\
$1960-69$ & 5197 & 29 \\
$1970-79$ & 6050 & 33 \\
$1980-92$ & & \\
Duration of employment (y): & 1060 & 6 \\
0.25 & 3358 & 19 \\
$0.25-<1$ & 2438 & 13 \\
$1-<2$ & 3171 & 18 \\
$2-4$ & 2885 & 16 \\
$5-9$ & 1259 & 7 \\
$10-14$ & 785 & 4 \\
$15-19$ & 985 & 5 \\
$20-29$ & 1828 & 10 \\
$30-39$ & 348 & 2 \\
$\geqslant 40$ & 18120 & 100 \\
Total & & \\
\hline
\end{tabular}

Table 2 Overall risk of cancer among Danish urban bus drivers and tramway employees

\begin{tabular}{lcccl}
\hline Stratification & Obs & $\operatorname{Exp}^{*}$ & SIR & (95\% CI) \\
\hline $\begin{array}{l}\text { Total cohort } \\
\text { Sex: }\end{array}$ & 2149 & 1727 & 1.24 & $(1.19$ to 1.30$)$ \\
$\quad$ Men & 2031 & 1635 & 1.24 & $(1.19$ to 1.30$)$ \\
$\quad$ Women & 118 & 92 & 1.28 & $(1.06$ to 1.53$)$ \\
$\begin{array}{l}\text { Duration of employment (y): } \\
\quad<0.25\end{array}$ & 72 & 69 & 1.04 & $(0.81$ to 1.31$)$ \\
$\geqslant 0.25$ & 2077 & 1655 & 1.25 & $(1.20$ to 1.31$)$ \\
\hline
\end{tabular}

*Reference=all Denmark.

personal identification number and for information on vital status and migration. In April 1968, the CPR was established in Denmark and all citizens were assigned a unique 10-digit personal identification number that included six digits for the date of birth. For people who died before 1 April 1968 the National Death Index, which dates back to 1943 , was consulted for date of death. For 483 people $(2.5 \%)$ we could not obtain information on vital status or date of death, so these were excluded from the cohort. Most of these people were born at the beginning of this century. Another 54 bus drivers and tramway employees $(0.3 \%)$ who died before 1 January 1943 were excluded, leaving 18120 people for analyses of risk of cancer.

Since January 1943 incident cancers, including benign brain tumours and bladder papillomas, have been reported to the Danish Cancer Registry. Computerised record linkage techniques were used to identify incident cancers among bus drivers and tramway employees with personal identification numbers (drivers alive at 1 April 1968). The remaining group was linked on the basis of name and dates of birth and death, and each match was verified by hand. The period of follow up for cancer began on the date of first employment in the CTC or 1 January 1943, whichever occurred last. The period ended on the date of death or emigration, or 31 December 1992, whichever occurred first. Cancers were classified according to a modified version of the International Classification of Diseases, the Seventh Revision (ICD-7). National incidence rates for all tumour categories, calculated according to sex, age, and calendar period (in five-year groups) were applied to the person-years of observation to obtain the number of cancers expected had the bus drivers and tramway employees experienced the same incidences as the general population of the country. For some subanalyses we applied incidences for Copenhagen.

The statistical tests were based on the assumption that the observed number of cancer cases in any specific category follows the Poisson distribution. Tests of significance and $95 \%$ confidence intervals (95\% CIs) were calculated for the standardised incidence ratio (SIR) as the ratio of the observed to expected cancers.

\section{Results}

The total cohort of 18120 bus drivers and tramway employees consisted of 16203 men and 1967 women, 386395 person-years of observation were accumulated over on average 21.3 years (range 26 days -71.8 years). The

Table 3 Risk of cancer among 15249 Danish urban male bus drivers and tramway employees employed more than three months

\begin{tabular}{|c|c|c|c|c|c|c|c|}
\hline \multirow[b]{2}{*}{ Site } & \multirow[b]{2}{*}{ Obs } & \multicolumn{3}{|c|}{ All Denmark* } & \multicolumn{3}{|c|}{ Copenhagen * } \\
\hline & & $\operatorname{Exp}$ & SIR & $(95 \% C I)$ & $\operatorname{Exp}$ & $S I R$ & $(95 \% C I)$ \\
\hline All malignant & 1966 & 1567 & 1.3 & (1.2 to 1.3$)$ & 1877 & 1.1 & (1.0 to 1.1 ) \\
\hline Mouth & 16 & 10 & 1.7 & (1.0 to 2.7 ) & 15 & 1.1 & (0.6 to 1.7 ) \\
\hline Pharynx & 22 & 12 & 1.9 & (1.2 to 2.8$)$ & 20 & 1.1 & (0.7 to 1.7 ) \\
\hline Oesophagus & 27 & 20 & 1.4 & (0.9 to 2.0$)$ & 28 & 1.0 & (0.6 to 1.4$)$ \\
\hline Stomach & 82 & 80 & 1.0 & (0.8 to 1.3$)$ & 77 & 1.1 & (0.8 to 1.3$)$ \\
\hline Colon & 123 & 103 & 1.2 & (1.0 to 1.4$)$ & 124 & 1.0 & (0.8 to 1.2$)$ \\
\hline Rectum & 105 & 87 & 1.2 & (1.0 to 1.5$)$ & 93 & 1.1 & (0.9 to 1.4$)$ \\
\hline Liver & 40 & 25 & 1.6 & (1.2 to 2.2$)$ & 37 & 0.8 & (0.8 to 1.6$)$ \\
\hline Pancreas & 57 & 46 & 1.2 & (0.9 to 1.6$)$ & 56 & 1.0 & (0.8 to 1.3$)$ \\
\hline Larynx & 39 & 29 & 1.4 & (1.0 to 1.9$)$ & 40 & 1.0 & (0.7 to 1.3$)$ \\
\hline Lung & 473 & 292 & 1.6 & (1.5 to 1.8$)$ & 390 & 1.2 & (1.1 to 1.3 ) \\
\hline Kidney & 83 & 52 & 1.6 & (1.3 to 2.0 ) & 64 & 1.3 & (1.0 to 1.6$)$ \\
\hline Bladder & 177 & 130 & 1.4 & (1.2 to 1.6$)$ & 165 & 1.1 & (0.9 to 1.3$)$ \\
\hline Prostate & 135 & 127 & 1.1 & (0.9 to 1.3 ) & 144 & 0.9 & (0.8 to 1.1$)$ \\
\hline Testis & 38 & 33 & 1.1 & (0.8 to 1.6$)$ & 37 & 1.0 & (0.7 to 1.4$)$ \\
\hline Skin non-melanoma & 219 & 205 & 1.1 & (0.9 to 1.2$)$ & 249 & 0.9 & (0.8 to 1.0$)$ \\
\hline Skin melanoma & 255 & 237 & 1.1 & (1.0 to 1.2$)$ & 286 & 0.9 & (0.8 to 1.0$)$ \\
\hline Brain & 36 & 50 & 0.7 & (0.5 to 1.0$)$ & 52 & 0.7 & (0.5 to 1.0$)$ \\
\hline Thyroid & 9 & 4 & 2.1 & (0.9 to 3.9$)$ & 5 & 1.9 & (0.9 to 3.6$)$ \\
\hline Leukaemia & 46 & 42 & 1.1 & $(0.8$ to 1.5$)$ & 42 & 1.1 & $(0.8$ to 1.5$)$ \\
\hline Other and unspecified & 16 & 12 & 1.3 & (0.8 to 2.1$)$ & 14 & 1.2 & (0.7 to 1.9$)$ \\
\hline
\end{tabular}

${ }^{\star}$ Refers to set of cancer incidences applied as reference. 
Table 4 Risk of cancer among 958 Danish urban female bus drivers and tramway employees employed for more than three months

\begin{tabular}{|c|c|c|c|c|c|c|c|}
\hline \multirow[b]{2}{*}{ Site } & \multirow[b]{2}{*}{ Obs } & \multicolumn{3}{|c|}{ All Denmark* } & \multicolumn{3}{|c|}{ Copenhagen * } \\
\hline & & $\operatorname{Exp}$ & $S I R$ & $(95 \% C I)$ & $\operatorname{Exp}$ & SIR & $(95 \% C I)$ \\
\hline All malignant & 111 & 88 & 1.3 & (1.0 to 1.5$)$ & 97 & 1.2 & (0.9 to 1.4$)$ \\
\hline Colon & 3 & 4 & 0.7 & (0.2 to 2.1$)$ & 4 & 0.8 & $(0.2$ to 2.2$)$ \\
\hline Rectum & 3 & 2 & 1.5 & (0.3 to 4.3$)$ & 2 & 1.5 & (0.3 to 4.3$)$ \\
\hline Pancreas & 2 & 1 & 1.6 & $(0.2$ to 5.9$)$ & 1 & 1.5 & $(0.2$ to 5.4$)$ \\
\hline Lung & 15 & 6 & 2.6 & (1.5 to 4.3$)$ & 7 & 2.2 & (1.2 to 3.6$)$ \\
\hline Bladder & 2 & 2 & 1.3 & (0.2 to 4.7$)$ & 2 & 1.0 & (0.1 to 3.8$)$ \\
\hline Breast & 29 & 26 & 1.1 & (0.8 to 1.6$)$ & 29 & 1.0 & (0.7 to 1.4$)$ \\
\hline Cervix uteri & 14 & 9 & 1.6 & (0.9 to 2.7$)$ & 8 & 1.7 & (0.9 to 2.8$)$ \\
\hline Corpus uteri & 4 & 4 & 1.0 & $(0.3$ to 2.5$)$ & 4 & 0.9 & $(0.2$ to 2.3$)$ \\
\hline Ovary & 7 & 5 & 1.5 & (0.6 to 3.0$)$ & 5 & 1.4 & (0.6 to 2.8$)$ \\
\hline Skin, non-melanoma & 9 & 10 & 0.9 & (0.4 to 1.8$)$ & 13 & 0.7 & (0.3 to 1.3$)$ \\
\hline Skin, melanoma & 11 & 14 & 0.8 & (0.4 to 1.5$)$ & 17 & 0.6 & $(0.3$ to 1.1$)$ \\
\hline Brain & 5 & 3 & 1.6 & (0.5 to 3.8$)$ & 3 & 1.7 & $(0.6$ to 4.0$)$ \\
\hline Other and unspecified & 2 & 0.5 & 3.7 & (0.4 to 13.4$)$ & 0.7 & 3.0 & (0.3 to 11.0$)$ \\
\hline
\end{tabular}

${ }^{\star}$ Refers to set of cancer incidences applied as reference.

Table 5 Risk of cancer and period of first employment among male Danish urban bus drivers and tramway employees

\begin{tabular}{lrrll}
\hline Stratification & Obs & Exp* & SIR & (95\% CI) \\
\hline All malignant cancers: & 194 & 149 & 1.30 & $(1.13$ to 1.50$)$ \\
$\quad 1900-19$ & 513 & 382 & 1.34 & $(1.23$ to 1.46$)$ \\
$1920-39$ & 772 & 628 & 1.23 & $(1.14$ to 1.32$)$ \\
$1940-49$ & 195 & 142 & 1.37 & $(1.18$ to 1.57$)$ \\
$1950-59$ & 59 & 48 & 1.22 & $(0.93$ to 1.58$)$ \\
$1960-69$ & 171 & 154 & 1.11 & $(0.95$ to 1.29$)$ \\
$1970-79$ & 63 & 66 & 0.95 & $(0.73$ to 1.22$)$ \\
$\geqslant 1980$ & & & & \\
Lung cancer: & 48 & 21 & 2.32 & $(1.71$ to 3.08$)$ \\
$1900-19$ & 140 & 76 & 1.85 & $(1.55$ to 2.18$)$ \\
$1920-39$ & 188 & 129 & 1.45 & $(1.25$ to 1.68$)$ \\
$1940-49$ & 52 & 27 & 1.96 & $(1.47$ to 2.57$)$ \\
$1950-59$ & 9 & 9 & 1.02 & $(0.46$ to 1.93$)$ \\
$1960-69$ & 24 & 23 & 1.05 & $(0.67$ to 1.56$)$ \\
$1970-79$ & 13 & 8 & 1.65 & $(0.88$ to 1.78$)$ \\
$\geqslant 1980$ & & & &
\end{tabular}

$\star$ Reference $=$ all Denmark.

Table 6 Risk of cancer among Danish urban bus drivers and tramway employees

\begin{tabular}{|c|c|c|c|c|c|c|}
\hline \multirow[b]{3}{*}{ Sex/site } & \multicolumn{6}{|c|}{ Time since first employment $(y)$} \\
\hline & \multicolumn{2}{|c|}{$0-14$} & \multicolumn{2}{|c|}{$15-29$} & \multicolumn{2}{|l|}{$\geqslant 30$} \\
\hline & $O b s$ & SIRt & $O b s$ & SIRt & $O b s$ & SIRt \\
\hline \multicolumn{7}{|l|}{ Men: } \\
\hline All malignant & 260 & 1.1 & 340 & $1.2^{\star}$ & 1366 & $1.3^{\star \star}$ \\
\hline Mouth & 2 & 1.0 & 3 & 1.7 & 11 & $1.9^{\star}$ \\
\hline Pharynx & 2 & 0.8 & 6 & 2.2 & 14 & $2.1^{\star}$ \\
\hline Oesophagus & 4 & 1.6 & 1 & 0.3 & 22 & $1.6^{\star}$ \\
\hline Colon & 14 & 1.1 & 16 & 1.0 & 93 & $1.3^{\star}$ \\
\hline Rectum & 10 & 1.1 & 17 & 1.1 & 78 & $1.3^{\star}$ \\
\hline Liver & 2 & 1.2 & 2 & 0.8 & 19 & $1.7^{\star}$ \\
\hline Larynx & 9 & 2.2 & 12 & $1.9^{\star}$ & 18 & 1.0 \\
\hline Lung & 35 & 1.2 & 77 & $1.5^{\star \star}$ & 361 & $1.7^{\star \star}$ \\
\hline Kidney & 9 & 1.3 & 20 & $1.8^{\star}$ & 54 & $1.6^{\star \star}$ \\
\hline Bladder & 19 & 1.3 & 28 & 1.3 & 130 & $1.4^{\star \star}$ \\
\hline \multicolumn{7}{|l|}{ Women: } \\
\hline All malignant & 59 & 1.2 & 46 & $1.4^{\star}$ & 6 & 1.2 \\
\hline Lung & 3 & 1.3 & 10 & $3.5^{\star \star}$ & 2 & 3.8 \\
\hline Cervix uteri & 12 & $1.8^{\star}$ & 2 & 1.1 & 0 & - \\
\hline
\end{tabular}

${ }^{\star} \mathrm{p}<0.05 ;{ }^{\star \star} \mathrm{p}<0.001$

$\dagger$ Reference=all Denmark.

Table 7 Risk of lung cancer among Danish male urban bus drivers and tramway employees

\begin{tabular}{|c|c|c|c|c|c|c|}
\hline \multirow[b]{3}{*}{ Duration of employment (y) } & \multicolumn{6}{|c|}{ Time since first employment (y) } \\
\hline & \multicolumn{2}{|c|}{$0-14$} & \multicolumn{2}{|c|}{$15-29$} & \multicolumn{2}{|l|}{$\geqslant 30$} \\
\hline & Obs & SIR & Obs & SIRt & Obs & SIRt \\
\hline$<0.25$ & 2 & 1.2 & 1 & 0.6 & 9 & 1.1 \\
\hline $0.25-<1.5$ & 5 & 1.0 & 11 & 1.5 & 57 & $2.0^{\star}$ \\
\hline $1.5-4$ & 9 & 1.3 & 11 & 1.5 & 48 & $1.7^{\star}$ \\
\hline $5-14$ & 17 & 1.3 & 26 & $2.5^{\star}$ & 70 & $2.1^{\star}$ \\
\hline$\geqslant 15$ & 3 & 0.7 & 28 & 1.1 & 188 & $1.5^{\star}$ \\
\hline
\end{tabular}

${ }^{\star} \mathrm{p}<0.0001$.

†Reference=all Denmark. characteristics of the cohort are shown in table 1. A total of $13757(75 \%)$ bus drivers and tramway employees were employed for at least one year and $1060(6 \%)$ for $<3$ months.

Overall, 2149 cancers were diagnosed among bus drivers and tramway employees with 1726 expected yielding a significantly increased SIR of 1.24 (table 2). Persons employed for $<3$ months had an SIR of 1.04, whereas people employed for $>3$ months had a significantly increased SIR of 1.25 (table 2).

The risk pattern among men employed for $>3$ months (table 3) showed significant excesses for cancers of the mouth (SIR 1.7) and pharynx (SIR 1.9), colon (SIR 1.2), rectum (SIR 1.2), and primary liver (SIR 1.6), larynx (SIR 1.4), lung (SIR 1.6), bladder (SIR 1.4), and skin (SIR 1.1) when compared with the expected number of cancers based on national reference rates. Non-significantly increased risks were found for all other major cancer sites, except for a significant deficit of brain cancer (SIR 0.7).

When cancer rates based on the Copenhagen population were used as reference, the overall cancer risk was 1.1 among male bus drivers and tramway employees who had been employed for $>3$ months. This is only marginally significant (table 3). However, the risk for lung cancer remained significantly increased with SIR 1.2 .

The overall cancer risk among women employed for $>3$ months was 1.3 which was of borderline significance (table 4). Among women it was the risk of lung cancer that was significantly increased when the national reference (SIR 2.6) was used as well as when Copenhagen was used as standard (SIR 2.2).

Table 5 shows that the risks for all malignant cancers and lung cancer were increased irrespective of calendar period for first employment. In table 6 the Copenhagen urban bus drivers and tramway employees were grouped according to time since first employment. In the male group with $0-14$ years of latency time no significant increase in risk of cancer was found. The risk of cancer among men in the 15-29 years latency group was significantly increased for all malignant cancers and three specified cancer sites. The risk of cancer after $\geqslant 30$ years of latency time was significantly increased for nine cancer sites. Among women we saw a significantly increased risk for cervical cancer in the group with $0-14$ years of latency time. The risk of cancer among women in the 15-29 years latency group was significantly increased for all malignant cancers and lung cancer. The risk after $\geqslant 30$ years of latency time was not significantly increased among women.

Apparently the risk pattern for lung cancer was not influenced by duration of employment (table 7). After 30 years of latency time we saw, however, a significant increase in lung cancer even after 3-17 months of employment.

\section{Discussion}

In this study of urban bus drivers and tramway employees ever employed in Copenhagen from 1900 onward we found an excess risk of cancer of $25 \%$. Increased numbers of cancers of the 
larynx, liver, mouth, and pharynx mainly caused this cancer risk. The results for lung cancer were especially noteworthy with a $60 \%$ excess risk for men and $160 \%$ for women.

It is always a possibility that estimates of excess risk are due to chance. However, the size of the present study and the consistent pattern of an increased risk make this explanation less likely. Geographical and demographic factors may have an influence too. There is an almost twofold risk of incidence of lung cancer among people living in Copenhagen compared with people living in the rural areas of Denmark. ${ }^{5}$ In a recent study, Engholm et $a l^{6}$ found that smoking is the main factor behind this difference in lung incidence of cancer. Even if we assume that all the bus drivers and tramway employees live in Copenhagen and we use cancer rates for the capital population as standard we find a significantly increased risk of lung cancer. However, the personnel employed by the CTC do not live only in Copenhagen. According to a 1996 survey of 113 bus drivers in Copenhagen one third of the bus drivers live in Copenhagen, one third live in the suburban area of Copenhagen, and one third live outside greater Copenhagen (Knudsen LE, National Institute of Occupational Health, Denmark and Effersøe $\mathrm{H}$, The Copenhagen Traffic Company, District 1, Copenhagen, Denmark, personal communication, 1997). Use of the Copenhagen population as the standard may therefore underestimate the excess risk.

Tobacco smoking is an important risk factor for lung cancer and, to some extent, also bladder cancer. In this cohort study we did not have any data on smoking but in a survey carried out in 1978 the smoking habits of 1631 city bus drivers in Copenhagen and two other cities were compared with participants in a general health survey in Glostrup. ${ }^{7}$ Glostrup is a suburb of Copenhagen, which is used in many studies in Denmark because it is considered to be representative of the Danish population. There was a higher percentage of heavy smokers among bus drivers aged 25-44 years than among the suburban population in the same age group. Among people aged 45-64 there were similar smoking habits. In another survey in $1980-5$ of 26 bus drivers $50 \%$ were smokers. ${ }^{8}$ According to an annual interview survey comprising about 20000 Danes, the alterations in the smoking habits from 1970 to 1987 were reviewed. ${ }^{9}$ The smoking rates for men in Denmark in 1970 and 1987 were 68\% and $50 \%$, respectively. The rates for men in Copenhagen in the same years were $74 \%$ and $52 \%$, respectively. Bus drivers belong to the occupational group of lower officials where the smoking rate in 1970 was $75 \%$ and in 1987 was $54 \%$. If these data are representative for all the CTC bus drivers and tramway employees in 1970 the bus drivers had the same rate of smoking as the Copenhagen population. In 1987 the smoking habits among bus drivers were above the Danish rates as well as the rates for the Copenhagen population. This means that some of the increased risk, but not all of it, may be explained by excess tobacco smoking. When adjusting the risk by use of the male population of Glostrup as reference we found a relative risk of lung cancer attributable to smoking of 1.2 among bus drivers aged 25-44 and 1.0 among bus drivers aged $45-64$ years. ${ }^{10}$ When the Danish cancer rates were used the risk of lung cancer was 1.6 therefore an increased risk of lung cancer of $40 \%-60 \%$ among bus drivers and tramway employees can not be attributed to smoking.

Diesel exhaust may be a carcinogen in humans. ${ }^{4}$ Many studies have associated exposure to diesel exhaust with the risk of getting cancer. Studies were performed on lorry drivers, ${ }^{11-12}$ railway workers, ${ }^{13-15}$ dock workers,${ }^{16}$ heavy equipment operators, ${ }^{17}$ taxi drivers, ${ }^{18-19}$ and bus drivers. ${ }^{12} 2021$ Based on six studies $^{11} 1316^{23-25}$ in which an attempt had been made to measure current diesel exposure and in which smoking data were available Steenland $e t a l^{26}$ estimated that the combined relative risk of lung cancer in populations exposed to diesel versus non-exposed populations was 1.31 (95\% CI 1.13 to 1.44 ). The authors of another recent comprehensive review ${ }^{27}$ concluded that despite 45 years of studies no positive epidemiological evidence of a lung cancer risk due to diesel exhaust has materialised yet.

Bus drivers and tramway employees are exposed to general air pollution from traffic, which has changed greatly during the long period covered in this study. The first petrol engined bus was introduced in Copenhagen in 1913, and in 1936 the first diesel powered bus was introduced. Gradually, they replaced petrol engined vehicles and in the 1960s they finally replaced trams also. However, during the second world war all buses were fuelled with petrol. There was no trend in the relative risk of all malignant cancer and lung cancer which could tell us whether petrol and diesel exposure was associated with the highest risk. The risk of lung cancer was increased irrespective of calendar period of first employment.

The risk for kidney cancer is still increased when an Axelson type adjustment for smoking was made. ${ }^{10}$ Kidney cancer has been connected with exposure to gasoline fumes ${ }^{28}$ although a firm conclusion on a such association was not drawn. ${ }^{29}$

The excess rates of liver cancer for bus drivers and tramway employees dropped when the Copenhagen population was used as a reference instead of the Danish population. This may be due to greater alcohol consumption in the Copenhagen area. However, we do not know the drinking habits among bus drivers and therefore we do not know which reference group is better.

Bus drivers and tramway employees spend all working hours close to the sources of air pollution. Another study confirmed that bus drivers were more exposed than other outdoor working groups. ${ }^{30}$ The levels of exposure inside and outside the bus were similar.

Supposing that occupational exposure to air pollution is the causal factor behind these findings we would expect the risk of cancer for drivers to increase when a biologically sufficient dose builds up - that is, to increase with duration of employment-but no cases should 
occur before a reasonable latency period has passed. We found that the incidence of cancer among male bus drivers and tramway employees with an accumulated employment period of $<3$ months was close to unity. Men in groups with longer employment periods had a significantly increased risk of cancer. However, other factors like exposure to air pollution in leisure time and former employments as well as lifestyle factors may also be influential.

The duration of employment was used as a surrogate measure for duration of exposure to air pollution. It was not possible to obtain the individual smoking history of all 18174 cohort members. A nested case-control study in which individual smoking information is requested should be carried out before any further conclusions on the aetiology can be drawn.

In conclusion, this retrospective cohort study showed that professional bus driving is associated with an excess risk of lung cancer. The risk of several other cancer sites is also increased. Additional studies taking individual lifestyle factors into consideration are recommended.

We are very grateful to Mr Visti Birk Larsen, Mrs Andrea Meersohn, and Mr Kenneth Olskaer for their excellent technica assistance during this study. This work was funded by a gran from the Danish Strategic Environmental Research Programme.

1 Scrám RJ, Benes I, Binková B, et al. Teplice program-The impact of air pollution on human health. Environ Health Perspect 1996;104:699-714

2 World Health Organization Regional Office for Europe: Air quality guidelines for Europe. Copenhagen: WHO Regional Publications, 1987. (European Series, Vol 23.)

3 Pershagen G, Simonato L. Epidemiologic evidence on air pollution and cancer. In: Tomatis L, ed. Air pollution and human cancer. ESO Monographs. Berlin: Springer Verlag, 1990:63-74.

4 International Agency for Research on Cancer. IARC monographs on the evaluation of carcinogenic risks to humans. Vol 46. Diesel and gasoline engine exhaust and some nitroarenes. Lyon: IARC, 1989.

5 Friis S, Storm H. Urban-rural variation in cancer incidence in Denmark 1943-87. Eur f Cancer 1993;29:538-44.

6 Engholm G, Palmgren F, Lynge E. Lung cancer, smoking and environment: a cohort study of the Danish population BMF 1996;312:1259-63.

7 Laursen P, Netterstrøm B, Pedersen TK, et al. Buschaufforer arbejdsmiljø 1. Copenhagen: Institute of Social Medicine, 1980.

8 Friche C, Ryom P, Olsen HF, et al. Hjertesygdomme blandt buschauffører. Arbejdsmiljøfondet, 1988.
9 Nielsen PE, Zacho J, Olsen JA, et al. Ændringer i danskernes rygevaner 1970-1987. Ugeskr Laeger 1988;138:2229-33.

10 Axelson O. Aspects on confounding in occupational health epidemiology. Scand $\mathcal{F}$ Work Environ Health 1978;4:85-9.

11 Steenland K, Silverman DT, Hornung RW. Case-control study of lung cancer and truck driving in the Teamsters Union. Am f Public Health 1990;80:670-4.

12 Milne KL, Sandler DP, Everson RB, et al. Lung cancer and occupation in Alamada County: A death certificate case-control study. Am $\mathcal{F}$ Ind Med 1983;4:565-75.

13 Garshick E, Schenker MB, Muñoz A, et al. A case-control study of lung cancer and diesel exhaust exposure in railroad study of lung cancer and dis 1987;135:1242-8.

14 Howe GR, Fraser D, Lindsay J, et al. Cancer mortality (1965-1977) in relation to diesel fume and coal exposure in a cohort of retired railroad workers. $\mathcal{F}$ Natl Cancer Inst in a cohort of retired

15 Garshick E, Schenker MB, Muñoz A, et al. A retrospective cohort study of lung cancer and diesel exhaust exposure in railroad workers. Am Rev Respir Dis 1988;137:820-5.

16 Gustafsson L, Wall S, Larsson L-G, et al. Mortality and cancer incidence among Swedish dock workers-A retrospective cohort study. Scand $\mathcal{F}$ Work Environ Health 1986;12:22-

17 Wong O, Morgan RW, Kheifets L, et al. Mortality among members of a heavy construction equipment operators union with potential exposure to diesel exhaust emissions. Br f Ind Med 1985;42:435-48.

18 Buiatti E, Kriebel D, Geddes M, et al. A case control study Buiatti E, Kriebel D, Geddes M, et al. A case control study
of lung cancer in Florence, Italy. I Occupational risk factors. F Epidemiol Community Health 1985;39:244-50.

19 Borgia P, Forastiere F, Rapiti E, et al. Mortality among taxi drivers in Rome: a cohort study. $A m$ f Ind Med 1994;25:507-17.

20 Alfredsson L, Hammar N, Hogstedt C. Incidence of myocardial infarction and mortality from specific causes among bus drivers in Sweden. Int F Epidemiol 1993;22:5761.

21 Michaels D, Zoloth SR. Mortality among urban bus drivers. Int F Epidemiol 1991;20:399-404.

22 Waller RE. Trends in lung cancer in London in relation to exposure to diesel fumes. Environ Int 1981;5:479-83.

23 Boffeta P, Stellman S, Garfinkel L. Diesel exhaust exposure and mortality among males in the American Cancer Sociand mortality among males in the American Cancer

24 Boffeta P, Harris R, Wynder E. Case-control study on occupational exposure to diesel exhaust and lung cancer risk. Am F Ind Med 1990;17:577-91.

25 Gustavsson P, Plato N, Lindstrom E, et al. Lung cancer and exposure to diesel exhaust among bus garage workers. Scand $\mathcal{F}$ Work Environ Health 1990;16:348-54.

26 Steenland K, Loomis D, Shy C, et al. Review of occupational carcinogens. Am f Ind Med 1996;29:474-90.

27 Stöber W, Abel UR. Lung cancer due to diesel soot particles in ambient air? A critical appraisal of epidemiological studies addressing this question. Occup Environ Health 1996; 68 (suppl):S3-61.

28 Siemiatycki J, Gérin $\mathrm{M}$, Stewart $\mathrm{P}$, et al. Association between several sites of cancer and ten types of exhaust and combustion products. Scand $\mathcal{f}$ Work Environ Health combustion prod

29 McLaughlin JK. Renal cell cancer and exposure to gasoline: a review. Environ Health Perspect 1993;101(suppl 6):11114.

30 Wilhardt P, Breum NO, Hansen ÅM, et al. Exposure to air pollution in the transport sector - methods development. Copenhagen: National Institute of Occupational Health, 1996. 